\title{
History of Science, Technology, and Medicine: A Second Look at Joseph Needham
}

\author{
Florence Hsia \\ Dagmar Schäfer
}

\begin{abstract}
These essays take a second look at Joseph Needham (1900-1995), the British biochemist whose colossal publishing project with Cambridge University Press, Science and Civilisation in China (1954-), attracts and frustrates historians of science, medicine, and technology in equal measure. Current reflections on the state of play in these fields address the themes, methods, and approaches that Needham took seriously and, in many cases, pioneered. This Second Look section probes the contributions that Needham's work can still make to ongoing debates.
\end{abstract}

Tn 1954, Joseph Needham published the first installment of Science and Civilisation in China 1 (SCC) with Cambridge University Press as a down payment on his exploration of "China's hitherto unrecognized contributions to science, technology, and scientific thought." The productive challenges to a Eurocentric field that Needham unspooled over the following years succeeded-perhaps too well. While Needham professed confidence that the series' ensuing volumes - those that he would not live to see-would not alter his views, the posthumously published General Conclusions and Reflections (2004) to SCC gave ample evidence that both Needham's framing questions and his answers were losing their conceptual and methodological grip on the profession. ${ }^{1}$ While some researchers continue to wrestle with the perennial "Needham question" - Why did modern science develop in Renaissance Europe, and not elsewhere? - others refute its counterfactual, comparativist, or civilizational premises in order to

\footnotetext{
Florence Hsia is Professor of History of Science and Associate Vice Chancellor for Research in Arts and Humanities at the University of Wisconsin-Madison. Her research focuses on scientific communication, data practices, and cross-cultural knowledge production, with particular interests in the history of astronomy, print culture, and the intersections of science and religion. 4028 Mosse Humanities, 455 North Park Street, Madison, Wisconsin 53706, USA; florence.hsia@wisc.edu.

Dagmar Schäfer's research focuses on the history of China, science, and technology. She received her Ph.D. from the University of Würzburg in 1996. She has also worked and studied in the People's Republic of China, Taiwan, and the United States. From 2011 until 2015 she was Professor of Chinese Studies and History of Technology at the University of Manchester. She now directs Department III, "Artefacts, Action, Knowledge," at the Max Planck Institute for the History of Science in Berlin. Her publications include The Crafting of the Ten Thousand Things (Chicago, 2011) and Threads of Global Desires: Silk in the Pre-Modern World (Boydell \& Brewer, 2018). Boltzmannstraße 22, 14195 Berlin, Germany; dschaefer@mpiwg-berlin.mpg.de.

${ }^{1}$ Publisher's advertisement, "The Scientist's Bookshelf," American Scientist, 1954, 42:692; and Joseph Needham, Science and Civilisation in China, Vol. 7: The Social Background, Pt. 2: General Conclusions and Reflections, ed. Kenneth Girdwood Robinson, with contributions from Ray Huang (Cambridge: Cambridge Univ. Press, 2004) (hereafter cited as SCC, Vol. 7, Pt. 2). Compare Robinson, "Volume Editor's Preface," ibid., pp. xvii-xxiii; Mark Elvin, "Vale Atque Ave," ibid., pp. xxiv-xliii; and Needham, "Foreword" (1995), ibid., pp. xliv-li.
}

Isis, volume 110, number 1. (c) 2019 by The History of Science Society. All rights reserved. 0021-1753/2019/0110-0006\$10.00.

94 
launch alternative approaches to writing global histories of science. ${ }^{2}$ The study of science, medicine, and technology in China "on their own terms" (to borrow the title of Benjamin Elman's 2005 monograph) sidesteps Needham's central question altogether. ${ }^{3}$

Already, in his 1998 introduction to an Osiris volume tellingly entitled "Beyond Joseph Needham" (Needham had died just three years earlier), Morris Low found Needham's work increasingly irrelevant given the globalization of scientific research and development, together with China's changing status following the Cold War. The field, too, has moved away from Needham's dichotomies (East/West, traditional/modern, technology/science) and modern scientific categories to engage the challenges of a widening disciplinary and political remit. As president of the History of Science Society, Lynn Nyhart remarked in 2013 that the profession shows a shifting interdisciplinary profile, as scholars of literature, art, sociology, music, media, and communication joined its ranks. Postcolonial theory has motivated the reevaluation of science and technology studies" unthought geopolitics, and the possibilities of "Asia as method" have drawn scholars to develop subject positions from which to challenge Western dominance anew. ${ }^{4}$

Yet there are clear parallels between current debates in the history of science, technology, and medicine (HSTM) and the themes, methods, and approaches that Needham took seriously and, in many cases, pioneered, although clearly his terms are not ours: against Needham's vision of traditional and culturally specific sciences converging into modern world science stand our diverse perspectives on a globalizing HSTM; his historical materialism has turned into our "materiality"; inherent within our practice/theory debates are the lines he tried to draw between technology and science. Such observations prompt us to inquire more closely into what Needham - a man who once provisioned completely new subjects and viewpoints for major areas of concern among historians of science-can still contribute today, both to HSTM in Asia and, more generally, to the field's methods, contents, and approaches for readers of both Tech-

\footnotetext{
${ }^{2}$ For work that continues to focus on the "Needham question" see Pervez Hoodbhoy, Islam and Science: Religious Orthodoxy and the Battle for Rationality (London: Zed, 1991); Toby E. Huff, The Rise of Early Modern Science: Islam, China, and the West (Cambridge: Cambridge Univ. Press, 1993); George Saliba, Islamic Science and the Making of the European Renaissance (Cambridge, Mass.: MIT Press, 2007); H. Floris Cohen, How Modern Science Came into the World: Four Civilizations, One SeventeenthCentury Breakthrough (Amsterdam: Amsterdam Univ. Press, 2010); and Jin Dengjian, The Great Knowledge Transcendence: The Rise of Western Science and Technology Reframed (New York: Palgrave Macmillan, 2015). Studies that seek to refute the Needham question's premises include Nathan Sivin, “Why the Scientific Revolution Did Not Take Place in China-Or Didn't It?” Chinese Science, 1982, 5:45-66; G. E. R. Lloyd, Adversaries and Authorities: Investigations into Ancient Greek and Chinese Science (New York: Cambridge Univ. Press, 1996); Lloyd, The Ambitions of Curiosity: Understanding the World in Ancient Greece and China (New York: Cambridge Univ. Press, 2002); Lloyd and Sivin, The Way and the Word: Science and Medicine in Early China and Greece (New Haven, Conn.: Yale Univ. Press, 2002); Jack Goody, The Theft of History (Cambridge: Cambridge Univ. Press, 2006); Arun Bala, The Dialogue of Civilizations in the Birth of Modern Science (New York: Palgrave Macmillan, 2006): Kapil Raj, Relocating Modern Science: Circulation and the Construction of Knowledge in South Asia and Europe, 1650-1900 (Basingstoke: Palgrave Macmillan, 2007); Roger Hart, Imagined Civilizations: China, the West, and Their First Encounter (Baltimore: Johns Hopkins Univ. Press, 2012); and Bala and Prasenjit Duara, eds., The Bright Dark Ages: Comparative and Connective Perspectives (Leiden: Brill, 2016). ${ }^{3}$ Benjamin A. Elman, On Their Own Terms: Science in China, 1550-1900 (Cambridge, Mass.: Harvard Univ. Press, 2005); Carla Nappi, The Monkev and the Inkpot: Natural History and Its Transformations in Early Modern China (Cambridge, Mass.: Harvard Univ. Press, 2009); Dagmar Schäfer, The Crafting of the Ten Thousand Things: Knowledge and Technology in Seventeenth-Century China (Chicago: Univ. Chicago Press, 2011); and Catherine Jami, The Emperor's New Mathematics: Western Learning and Imperial Authority during the Kangxi Reign (1662-1722) (Oxford: Oxford Univ. Press, 2012).

${ }^{4}$ Morris F. Low, "Introduction," in "Beyond Joseph Needham: Science, Technology, and Medicine in East and Southeast Asia," Osiris, 1998, N.S., 13:1-8; Lynn K. Nyhart, "The Shape of the History of Science Profession, 2038: A Prospective Retrospective," Isis, 2013, 104:131-139, esp. pp. 133-135; and Fa-ti Fan, "Modernity, Region, and Technoscience: One Small Cheer for Asia as Method," Cultural Sociology, 2016, 10:361-366.
} 
nology and Culture and Isis. In this introduction we briefly characterize Needham's stance as scientist and historian before highlighting some key continuities between his scholarly labors and ours.

\section{JOSEPH NEEDHAM: SCIENTIST AND HISTORIAN}

In opening the first volume of SCC (1954), Needham explicitly distanced himself from familiar forms of oriental expertise associated with the merchant, the career diplomat, and the missionary. Instead he emphasized scientific training and research as an alternative kind of professionalism that set his study and analysis of "science and civilisation in China" apart from the imperialist structures-political, religious, economic - through which China experts had all too often gained their knowledge of the East. ${ }^{6}$

This was a significant stance to take in an increasingly complex postcolonial world. In 1962, only a year after the final surrender of Portuguese India to the Indian Republic and amidst an escalating border conflict with China, the Asiatic Society in Bengal-no longer a branch of the Royal Asiatic Society-decided to recognize Needham's "distinctive contribution to the sciences, and to the History of Sciences," by awarding him the Sir William Jones Memorial Medal, named for its founder, an orientalist scholar par excellence. Though unable to accept the honor in person owing to what he obliquely called "international circumstances," Needham held on nevertheless to an unshaken belief in the history of science as a form of what he called "supranational" scholarship, an optimism underwritten by his self-professed identity as a "working scientist" untrammeled by imperialist and colonialist agendas. ${ }^{7}$

It was, after all, Needham's accomplishments as a biochemist that opened the door to his work in 1940s China for the Sino-British Science Cooperation Office, an initiative sponsored by the British Council to support scientific exchange and research. The "guidance" concerning China's scientific heritage that scientists and scholars gave Needham in his visits to nearly three hundred universities, laboratories, and research institutes across Free China was, he later declared, essential to his historical project. ${ }^{8}$ These experiences fueled Needham's efforts to have science included in the United Nations' new organization to support postwar educational and cultural reconstruction. Responsible for the "S" in UNESCO (the United Nations Educational, Scientific, and Cultural Organization, established in 1946), Needham served as the first director of its natural sciences division, where he sought to promote scientific collaborations unrestricted by political boundaries and worked hard to shape a project that would prepare an ecumenical world history of all humankind. ${ }^{\text {? }}$

Like so many "Western advisers" before and since, Needham sought "to change China" for the better-and on political (leftist) and theoretical (Marxist) terms at odds with those on which not only Western "professional" orientalism (the civilizing mission) but also Western studies of the non-West (liberal modernization theory) had principally developed. And yet

\footnotetext{
5 B. V. Subbarayappa, “Joseph Needham's Perspectives on Indian Science: Some Reflections," Studies in the History of Natural Sciences, 2000, 10:218-225.

${ }^{6}$ Joseph Needham, Science and Civilisation in China, Vol. 1: Introductory Orientations, with Wang Ling (Cambridge: Cambridge Univ. Press, 1954) (hereafter cited as SCC, Vol. 1), p. 6.

${ }^{7}$ Sushil Kumar Mukherjee and Amitabha Ghosh, eds., The Life and Works of Joseph Needham (Calcutta: Asiatic Society, 1997), pp. xvi (“distinctive contribution"), xvii ("international circumstances"), xix ("supra-national").

${ }^{8}$ SCC, Vol. 1, p. 6; see the extensive acknowledgment of aid given by Chinese colleagues in this period at pp. 11-13. See also Thomas Mougey, "Needham at the Crossroads: History, Politics, and International Science in Wartime China (1942-1946)," British Journal for the History of Science, 2017, 50:83-109.

${ }^{9}$ Patrick Petitjean, "Anglo-French Civilities and Ecumenical Science," in Situating the History of Science: Dialogues with Joseph Needham, ed. S. Irfan Habib and Dhruv Raina (New Delhi: Oxford Univ. Press, 1999), pp. 167-183; and Poul Duedahl, "Selling Mankind: UNESCO and the Invention of Global History, 1945-1976," Loumal of World History, 2011, 22:101-133.
} 
the conception of science underwriting both the conditions and the contours of Needham's historical work left significant features of such intellectual formations intact. The most striking of these was his presumption that "universally valid world science, that is to say, 'modern' science," had originated in a particular time and place: early modern Europe. ${ }^{10}$

The "modern science" under which Needham organized his life as a politically engaged scientist and historian served him well as an analytical concept that made a particular version of scholarship possible - and attractive - in a world shattered by conflicts. But recognizing the presentism underwriting the Needham question and driving the entire SCC project is but a first step toward staking out the grounds on which local and global studies of history of science, medicine, and technology are possible for our time.

\section{EAST ASIAN HSTM AND COMPARATIVE HISTORY}

In 1995, Nakayama Shigeru conjured a pessimistic vision of the future of history of science, technology, and medicine in East Asia as a marginalized field caught in shallow cross-cultural comparison. ${ }^{11}$ Fortunately, this has not come to pass. Instead, a once identifiably regional branch of HSTM has grown into a thriving worldwide network of scholars with varied specialisms. The ongoing Science and Civilisation in China series itself has come to constitute an important cornerstone within an ever-growing literature with multiplying agendas and methodologies.

The "new axes of comparison" beyond the East/West dichotomy that Marta Hanson pinpointed in her major 2002 review have prospered, shedding light on the phenomenon of "intra-East Asian colonial science." Much as the historian Dipesh Chakrabarty has provincialized Europe in relation to India, the decolonization of East Asian HSTM, too, has influenced research in meaningful ways. Historians of Asia-together with those working in and on South Asia, Latin America, and Africa - are exploring what it means to use their region's history methodologically by "eschewing a naïve ontology of what 'Asia' or "East Asia' is." 12 Scholars are focusing less on "firsts" and "transfers" and more on diverse forms of mobility and circulation, as well as modes of appropriation, adaptation, and adoption. ${ }^{13}$ Diversity is key, but similarities and convergences have emerged as well.

The comparative possibilities developed for HSTM in East Asia can be extended to issues addressed by scholars working with other regions and temporalities, though questions and chronologies on the scale of Needham's SCC project are seldom addressed-perhaps because dislodging assumptions about progress, welfare, and modernity is easier said than done. ${ }^{14}$ Though

\footnotetext{
${ }^{10}$ Jonathan D. Spence, To Change China: Western Advisers in China, 1620-1960 (Harmondsworth: Penguin, 1980); and Joseph Needham, Science and Civilisation in China, Vol. 3: Mathematics and the Sciences of the Heavens and the Earth, with Wang Ling (Cambridge: Cambridge Univ. Press, 1959), p. 448. See also Gregory Blue, "Joseph Needham, Heterodox Marxism, and the Social Background to Chinese Science," Science and Society, 1998, 62:195-217; Paul A. Cohen, Discovering History in China: American Historical Writing on the Recent Chinese Past (New York: Columbia Univ. Press, 1984); and Jeffrey C. Alexander, "Modern, Anti, Post, and Neo: How Social Theories Have Tried to Understand the 'New World' of 'Our Time," Zeitschrift für Soziologie, 1994, $23: 165-197$. ${ }^{11}$ Nakayama Shigeru, "History of East Asian Science: Needs and Opportunities," Osiris, N.S., 1995, 10:80-94.

12 Marta E. Hanson, "New Directions in the History of Science in East Asia," East Asian Science, Technology, and Medicine, 2002, no. 19, pp. 107-115, on p. 114; Dipesh Chakrabarty, Provincializing Europe: Postcolonial Thought and Historical Difference (Princeton, N.J.: Princeton Univ. Press, 2000); and Fan, "Modernity, Region, and Technoscience" (cit. n. 4), p. 363.

${ }^{13}$ See, e.g., Florence Bretelle-Establet, ed., Looking at It from Asia: The Processes That Shaped the Sources of History of Science (Leiden: Brill, 2010); and Pamela H. Smith, ed., Entangled Itineraries: Materials, Practices, and Knowledges across Eurasia (Pittsburgh: Univ. Pittsburgh Press, 2019).

${ }^{14}$ For some recent efforts see the forum on "Provincializing STS" in East Asian Science, Technology, and Society, 2017, 11:209269; Jerry Liu and Kent Deng, eds., "Chinese Technological History: The Great Divergence,” special issue, History of Technology, 2009, 29; and Ian Inkster, "The West Had Science and the Rest Had Not? The Queries of the Mindful Hand," ibid., pp. $205-211$. Environmental history is a major exception to this rule.
} 
politically engaged in their sensitivity toward languages, agendas, and ideologies, studies today are more restricted in scope, less speculative, and rarely prospective. Needham's project made and continues to make visible the advantages and repercussions, the fallacies but also the notyet-seized opportunities, of historical work on a large scale.

\section{"CHINESE" KNOWLEDGE, TECHNOLOGY, AND SCIENCE}

While the rethinking of "East Asia" as a diverse, dynamic, and historically contingent entity characterizes much current East Asian HSTM, cultural and national identity creation constitutes perhaps the most lasting legacy of Needham's work. Only recently, South Korean academics launched a new initiative to create "A History of Science and Civilisation in Korea." Though its chief editor, Hong-key Yoon, distanced the project from what he characterized as Needham's presentism, the proposed English-language series is a project of visibility as much as of national pride, one that hinges substantially on Needham's example..$^{15}$

In foregrounding Chinese "civilisation" or "culture" (as terms of contrast and comparison, Needham used them interchangeably), the SCC project has provided much grist to the deflationary mill. ${ }^{16}$ Mark Gamsa has recently noted that "western academic writing has indeed pretty much stopped raising the question of national-specific thinking, or styles of reasoning," and suggests that the "ways of thinking" issue can be productively revisited through "a more nuanced terminology." A 2007 volume edited by Charlotte Furth, Judith T. Zeitlin, and Ping-chen Hsiung that focuses on specialist knowledge produced by doctors, judges, and philosophers in late imperial China is a model for how scholars can productively illuminate historically specific traditions without recourse to broad-brush claims for "Chinese" forms of reasoning. ${ }^{17}$

To be sure, Needham was hardly alone in propounding a "Chinese" way of thinking as part of his historical studies. As Steven Shankman and Stephen Durrant have suggested, the sinological enterprise "has been inherently comparative from its beginnings." A closer look at Needham's writings suggests, however, that he deployed terms like "China" and "Chinese" more for strategic purposes than with analytical precision. Needham valorized Chinese science, inverting his question about China's failures into a quest for the factors that had contributed to China's periodic successes in "gaining scientific knowledge and applying it for human benefit for fourteen previous centuries." He also idealized Chinese culture morally as a civilization of correct ideals and classless structures that had produced "great philosophers" who "agreed in seeing human nature as fundamentally good, and considering justice and righteousness as arising directly out of it by the action of what we in the West might call the "inner light." ${ }^{18}$ Especially in his public lectures, Needham depicted China as a unified sphere with cultural ideals, defined traditions, and scientific and technological achievements as consequential as those of Europe.

Needham's evaluation of Buddhism might, at first glance, seem to exemplify a strongly culturalist approach. Confucianism and Daoism feature prominently in History of Scientific Thought, the second volume of SCC that served as Needham's prolegomenon to his historical investigations, a nearly six-hundred-page survey of Chinese philosophy; Buddhism, in contrast, takes up less

\footnotetext{
${ }^{15}$ Hong-key Yoon, "Four Points to Be Considered When Writing 'A History of Science and Civilisation in Korea,'” EASTM, 2015, no. 42, pp. 73-92, esp. pp. 77-78, 86-87.

${ }^{16}$ See esp. Hart, Imagined Civilizations (cit. n. 2), Chs. 1-3.

${ }^{17}$ Mark Gamsa, "A Chinese Way of Thinking," Philosophv East and West, 2018, 68:42-58, on p. 42; and Charlotte Furth, Judith T. Zeitlin, and Ping-chen Hsiung, eds., Thinking with Cases: Specialist Knowledge in Chinese Cultural History (Honolulu: Univ. Hawai'i Press, 2007).

${ }^{18}$ Steven Shankman and Stephen W. Durrant, "Introduction," in Early China/Ancient Greece: Thinking through Comparisons, ed. Shankman and Durrant (Albany: State Univ. New York Press, 2002), pp. 1-13, on p. 3; and Joseph Needham, "History and Human Values: A Chinese Perspective for World Science and Technology," Centennial Review, 1976, 20:1-35, on pp. 2, 21.
} 
than forty pages. C. Pierce Salguero has contrasted Needham's “self-confessed love for China” with a negative view of Buddhism that led to a generational blindness toward Buddhist texts of great importance for the history of medicine and the body. How aware Needham was of the complexity of Chinese schools of thought when he compiled the volume in 1956 is not clear, but he had certainly decided on the critical forms of knowledge in Chinese history in light of their respective contributions to "the development of scientific thought." It was a conception of modern science that drove Needham's "blanket dismissal" of Buddhism in China, not its exogenous origins. ${ }^{19}$

If Needham emphasized antagonism between Buddhism and "indigenous philosophies," he also remarked repeatedly on its influence, both positive and negative. ${ }^{20}$ This is of a piece with his insistence on a capacious view of cultural diffusion and development that, in turn, made possible his understanding of modern science as culturally unbound. ${ }^{21}$ While many, if not most, HSTM scholars today will likely demur in the face of Needham's implacable insistence on "modern science" and its analytical utility, Karine Chemla and Evelyn Fox Keller have recently highlighted how certain forms of comparative history led Needham to voice concerns over cultural essentialism that still have purchase for us today. ${ }^{22}$

Needham still figures as an advocate for China's sciences, a historicized repository of reference material, and an antagonist for the current generation of new approaches, topics, and agendas. Yet the premises, questions, and connections he posed were of a scope and character that continue to provoke. His challenge was to take up arms for a new field of research. With the battle of legitimacy won, East Asian HSTM - together with the profession as a whole - can afford to take a second look at what Needham's scholarship may yet have to tell us about culturally specific and globally sensitive histories of science, technology, and medicine.

\footnotetext{
${ }^{19}$ Joseph Needham, Science and Civilisation in China, Vol. 2: History of Scientific Thought, with Wang Ling (Cambridge: Cambridge Univ. Press, 1956) (hereafter cited as SCC, Vol. 2), pp. 396-431 (discussion of Buddhism), 1 ("development of scientific thought”); and C. Pierce Salguero, “"This Fathom-Long Body”: Bodily Materiality and Ascetic Ideology in Medieval Chinese Buddhist Scriptures," Bulletin of the History of Medicine, 2018, 92:237-260, on pp. 238 ("self-confessed love for China"), 258 ("blanket dismissal").

${ }^{20}$ SCC, Vol. 2, p. 410.

${ }^{21}$ SCC, Vol. 1, pp. 150-238; and SCC, Vol. 7, Pt. 2, pp. 200-203.

${ }^{22}$ Karine Chemla and Evelyn Fox Keller, "Introduction," in Cultures without Culturalism: The Making of Scientific Knowledge. ed. Chemla and Fox Keller (Durham, N.C.: Duke Univ. Press, 2017), pp. 1-25, esp. pp. 6-7. See also Chemla's 2014 Sarton Chair lecture, "The Dangers and Promises of Comparative History of Science," in Sartoniana, ed. Robert Rubens and Maarten Van Dyck (Ghent: Academia, 2014), pp. 13-44.
} 